\title{
Seed-borne fungi, especially pathogens, of spring wheat
}

\author{
MOHAMED KHAIRAT MOHAMED DAWOOD \\ Institute of Plant Protection, Laboratory of Phytopathology, \\ Academy of Agriculture, 50-205 Wrocław, Cybulskiego 32, Poland
}

\begin{abstract}
Dawood M. K. M.: Seed-borne fungi, especially pathogens, of spring wheat, Acta Mycol. 18(1): 83-112, 1982.

The present investigations were carried out on seeds of the spring wheat var, 'Kolibri'. Storage was at either 12 or $15 \%$ moisture seed content, and temperature degrees of labile, $0^{\circ} \mathrm{C}, 25-30^{\circ} \mathrm{C}$ for a periods extended to 18 months. Seeds remained healthy at $12 \%$ M. C., and $15 \%$ and $0^{\circ} \mathrm{C}$. Mycological analysis of fresh and stored seeds revealed great difference among their fungal flora. Sporadic amounts of certain fungal pathogens, from the Fusarium genus, were isolated from seeds. In relation of seed-borne fungi to the health state of plants developing, results of pot experiments showed the possibility of spread certain pathogens of Fusarium from seed to stem of the devaloping plant. The fungal communities of seeds or plants does not imit, in general, the development of these pathogens Fusarium culmorum, $F$. poae, $F$. equiseti. Fusarium culmorum was found, under the present work, to be a most severe infectous agent of foot rot disease of wheat crop var. 'Kolibri'.
\end{abstract}

\section{INTRODUCTION}

It is well known that seeds can harbour quite a lot of different microflora, although not all are epiphytic. Fungi which form the major part of them an be carried on or in the seed. The latter in its dormant state rarely provides a suitable condition for fungi associating. The active growht of them begins on sowing the seed. They go into great interactions among them and, with the germinating seed (Dom mergues, Mangenct-1979). Thus spread of seedborne fungi especially the pathogen ones is more ; elated to movement of seed.

The aim this work is to survey the fungi, especially pathogens, associated with fresh and stored seeds of spring wheat, as well as to study the effect of storage of the seeds on the health state of plants 
developing under different sowing conditions. Furthermore, this work is intended to study the biotic effect of fungal seeds or plant communities on development of certain fungal pathogens namely, Fusarium culmorum, F. poae, F. equiseti and Rhizoctonia solani.

\section{REVIEW OF LITERATURE}

Cereal seeds, including wheat, are liable to attack by different species of fungi upon harvest and during storage.

Many workers (Darpoux, Ponchet 1957; Ryka 1963; E, acicowa 1964a; Christensen, Kaufmann 1965) surveyed different species of fungi from the fresh harvested wheat seeds. These species belong to the genera Alternaria, Cladosporium, Helminthosporium, Fusarium, Septoria, Penicillium, Pythium, Rhizopus and Mucor.

During the storage period of seeds some microorganisms may die out or even decrease whereas others may develop. The latter is especially the case of storage fungi from the Aspergillus and Penicillium genera. In this connection, condition of storage especially moisture seed content and temperature of storage play an important role. Lutey and Christensen (1963) reported loss in viability of species belongs to the genera: Fusarium, Helminthosporium and Alternaria on barley seeds stored at $14 \%$ M.C. and $20^{\circ} \mathrm{C}$ for 6 months. $\mathrm{Chr}$ istensen and $\mathrm{K}$ a u f $\mathrm{m}$ a $\mathrm{n} \mathrm{n}$ (1968) reported that Fusarium spp. dies relatively rapidly in seeds stored at $12-13 \%$ M.C. and at a temperature above $21^{\circ} \mathrm{C}$. Golubchuk et al. (1965) noted a reduction of the amount of different species belonging to the storage fungi on spring wheat seeds stored at $12 \%$ M.C. and $24^{\circ}$, and $38^{\circ} \mathrm{C}$. By contrast, Soeger-Domenigg et al. (1955) reported high levels of these fungi on the same seeds at $14 \% \mathrm{M}$. C. and $20-24^{\circ} \mathrm{C}$. T u ite and $\mathrm{Chr}$ istensen $(1957 \mathrm{~b})$ reported gradual invasion of wheat seeds, stored at $13-13,6^{\circ} \%$ M.C. and $25^{\circ} \mathrm{C}$ for 6 months, by Aspergillus amstelodami. On the other hand A. repens parasitized the same seeds more slowly. Storage fungi do not invade wheat seeds at any degree on harvest ( $\mathrm{S}$ a u e r, C hristen se n 1966). rhat result was also obtained by $\mathrm{N}$ a rkiew ic z-Jodko (1978) on rye and oat seeds.

Some trials were made in order to define sources of contamination with storage fungi. Tuite and $\mathrm{Chr}$ istensen (1957a) reported that inocula of storage fungi are uncommon in the air of ripe wheat sields. These inocula were abundant in the air of either country or terminal elevators. Flannigan (1978) listed several sources of primary contamination with storage fungi. These sources were soil, culms and basal segments of plant leaves, storage tanks and, sacks. 
Seed-borne mycoflora may caused serious diseases for either seed or the developing plant. Neerga ard (1977) listed eight types of seed diseases. He also noted several seed-borne pathogens of different crops including wheat. Brooks (1953), and Butler and Gones (1955). described several diseases of wheat plants caused by seed-borne mycoflora.

Foot rot disease is one of the most important diseases of cereal crops. Many of fungi transmited with seeds can cause it. Colhoun and Park (1964) noted the occurrence of this disease on wheat plants developed from seeds inoculated with Fusarium culmorum, F. graminearum or $F$, avenaceum. Cassini (1970) found that disinfection of wheat seeds before planting has a good effect in reducing the percentage of occurrence of this disease.

Different authors (Nespiak 1963; Cook 1968) surveyed the fungi which occupied stem bases of plants showing symptoms of the foot rot disease. These fungi were mostly species of the Fusarium genus, especially $F$. culmorum. Bruehl (1951) tested the pathogenicity of Rhizoctonia solani on wheat plants. His results sugested the possibility of this fungus in causing symptoms of foot rot disease.

Numerous investigations were carried out in Poland (Truszkowska, Schneider 1971; Truszkowska 1972; Truszkowska et al. 1971, 1972a, 1972b) on the health state of different kinds of plants. Results obtained by them indicate that a variety of factors including, moisture content of seeds, and temperature of storage has a effect upon the health state of seedlings developing in either nonsterilized or sterilized soil. The results obtained indicated that one of the favourable conditions for seedling emergence and growth are microflora of soil.

The different interactions, including "antagonism, among fungi associated with seeds or plants may affect the development of certain fungal pathogens. Mańka (1968) designed a method for determine the biotic effect of fungal communities isolated from soil, rhizosphere, and roots of Pinus sylvestris on the development of Heterobasidion annosus. Application of this method by other workers (M a n k a, Kowalski $1968 ;$ Dor end a 1974) lead to accurate results. These results marcedly showed the native relation between a given pathogen other associated species.

\section{MATERIAL AND METHODS}

Uncertified seeds of the spring wheat var. 'Kolibri' from the 1976 harvest constituted the base material throughout the present work. Storage trials commenced on October 25, 1976. Samples of seeds with 
moisture content $1:$ and $15 \%$ were stored at different temperature degrees of labile, $0^{\circ}, 25-30^{\circ} \mathrm{C}, 6$ combinations were used. 'Tightly closed glass bottles (18 cm diam., and $8 \mathrm{~cm}$ high) were employed as seed containers; 5 bottles per one combination. Period; of storage for each combination were 6,12 and 18 months.

The germination capacity of seeds was determined according to a method described by Dorywalski et al. (1964). Six and four samples of the fresh and stored seeds respecively were used for this purpose. Each sample contains 100 seeds.

The mycological analysis of fresh seeds was on October 30, 1976. The same analysis of stored seeds was performed on April 23, November 4, 1977, and March 29, 1978. Two applicable methods of Ulster and the modified Ulster method (M a lone, M uskett 1964) were used for this purpose. 200 and 100 seeds of fresh and stored seeds respectively, were either nondisinfected or disinfected and placed on the surface of $2 \%$ malt extract agar in Petri plates, 10 seeds per plate. Surface disinfection of fresh seeds was done by dipping them in sodium hypochlorite solution $(1 \%$ available chlorine) for $10 \mathrm{~min}$. Then they were drained off on sterile filter paper and transfered immediately onto the surface of medium. Surface disinfection of the stored seeds was carried out by immersing them in $90 \%$ ethyl alcohol, and then in $0,1 \%$ solution mercuric chloride for $1 \mathrm{~min}$. each. After this, the seeds were rinsed three times in sterile distilled water. Incubation of plates and their seeds were at $20-22^{\circ} \mathrm{C}$ for up to 14 days.

Pot experiments were carried out by sowing seeds stored 6 months in either nonsterilized or sterilized soil; 24 treatments were done, these treatments were on the basis of 4 treatments for each storage combination as follow:

1 - sowing nondisinfected seeds in nonsterilized soil,

2 - sowing disinfected seeds in nonsterilized soil,

3 - sowing nondisinfected seeds in sterilized soil,

4 - sowing disinfected seeds in sterilized soil.

Surface disinfection of seeds was carried out was mentioned above. Soil used consisted of clay and sand $(1: 1)$. Sterilization of it took place two weeks before. It was autoclaved three times for one hour with 24 hour intervals between sterilizations. Enamel pots $(20 \mathrm{~cm}$ diameter, and $18 \mathrm{~cm}$ deep) were used as soil containers; 120 pots were used, 5 per each treatment. Procedure of planting took place by sowing 100 seeds per treatment (20 per pot). The sown seeds were covered with a thin layer $(2 \mathrm{~cm}$ thick) of the same soil. All the pots (after sowing seeds) were covered with glass sheets. Irrigation took place immediately after sowing and during the experiment period with 4 days intervals; 
$200 \mathrm{ml}$ tap water were used for every pot. All the pots wer kept at the experimental farm of the Wrockaw Agricultural Academy in Pawlowice. The period of the experiment extended to 3 months from April 18, 1977.

Three agricultural values were estimated as follows:

1 - percent of seedlings emerging after 15 days of sowing,

2 - length of the stem and ear of each cultivated plant,

3 - percentage of plants showing symptoms of foot rot disease.

The mycological analysis of the diseased plants was carried out on July 13, 1977; 10 plants showing clear symptoms were selected at each treatment ( 2 plants per pot). Cylindrical segment (3-5 $\mathrm{mm}$ long) complete in diameter were cut transversally from the stem base of each selected plant. The cut segments (3 per plant) were placed on the surface of potato glucose agar in Petri dishes (6 for one dish). Prior to placing, the segments surfaces were disinfected by immersing these parts of plants first in $50 \%$ ethyl alcohol and then in $0,1 \%$ solution of mercuric chloride for 40 seconds in each. Afterward, they rinsed thrice in sterile distilled water. All the inculated dishes were incubated at $20-22^{\circ} \mathrm{C}$ for up to 14 days.

The biological experiments were carried out under laboratory conditions. The fungal communities isolated from either seeds or plants were individually studied in their biotic effect on the development of certain isolated pathogens. Such pathogens were Fusarium culmorum, $F$. poae, $F$. equiseti and Rhizoctonia solani. The present experiments based upon the biotic series method of $\mathrm{M}$ a n $\mathrm{ka}$ (1968). Throughout these studies, all species of fungi except those of pathogens were used. Degree of biotic effect of each species was estimated according to a scale designed by the author mentioned above. Summary biotic effect of each fungal community was calculated by the algebric sum of results obtained by multipling biotic degree effect of every species, within community, in its isolated number of colonies.

Pathogenicity experiments were carried out on July 3, 1978. Two fungal species namely, $F$. culmorum and $F$, poae were tested in their pathogenic properties. Seedling developed from seeds stored at either 12 or $15 \% \mathrm{M}$. C. and $0^{\circ} \mathrm{C}$ were used for this purpose.

Three successive stages were done as follow:

1 - Artificial infection of seedlings in vitro.

Test tubes contain sterilized Knop solution medium were used for this purpose. The method used was described by Messiaen et al. (1959); 100 seeds (50 at each M. C.) were disinfected and then placed at the upper part of the medium. One seed was placed per tube. Cultural agar discs (7 days old, and $4 \mathrm{~mm}$ diam.) of the fungi be test, were 
superficially applied to the lower part (ore inoculum per tube). Surface disinfection of seeds was carried out similarly as described earlier; 25 tubes were inoculated with either Fusarium culmorum or $F$, poae. Control treatments were done similarly with the absence of the fungal mycelium. All treatments and controls were kept at absolute darkness and under artificial day light for 6 and 15 days respectively.

2 - Trans seedlings into either non sterilized or sterilized soil.

All the healthy seedlings were transferred to plastic cups contains either non sterilized or sterilized soil. One seedling was planted per one cup. Soil used consist of sand and clay $(1: 1)$. Sterilization of soil was performed as described earlier. Period of this stage was one month. During this period, all the plants were kept under artificial day light and irrigated twice a week.

\section{3- - Transplanting in to soil from field.}

All the healthy plants were transferred to enamel pots containing soil from field. 4-5 plants were transferred per pot. All the plants were kept under artificial day light for one month, and irrigated twice a week.

Reisolation experiments of the fungi were carried out during, and at the end of the first and third period respectively. Transversal segments were cut from the basal portion of each plant. The cut fragments were surface disinfected and then placed on the surface of potato glucose agar in Petri dishes. Surface disinfection was done by immersing these parts in $50 \%$ ethyl alcohol and $0,1 \%$ solution mercuric chloride. Period of immersion was 20 to 40 seconds in each solution according to the material age. Then they were rinsed thrice in sterile distilled water. All the inoculated dishes were incubated for up to 14 days at $20-22^{\circ} \mathrm{C}$.

Throughout the present work all the isolated colonies of fungi were determined by the author using different publications ( $\mathrm{C}$ h iver s 1915; Wollenweber, Reinking 1935; Neergaard 1945; Miller 1946; Raper, Thom 1949; Dade 1949; Raiłlo 1950; Benjamin 1955; Hesseltine 1955; Hesseltine, Fennell 1955; Brown, Smith 1957; v. Arx 1957, 1974; Raper 1957; Gilman 1959; Barnett 1960; Ames 1961; Whiteside 1961; Eacicowa 1963, 1964b; Malone, Muskett 1964; Ellis, Hesseltine 1965; Raper, Fennell 1965; Simmons 1967; Hess et al. 1968; Hess, Stocks 1969; R if a 1 1969; Zycha et al. 1969; Domsch, Gams 1970; Dorenbosch 1970; Parmeter 1970; Booth 1971, 1975; Ellis 1971; Barron 1972; Gams 1971). 


\section{RESULTS}

\section{Germination experiments}

Results of germination experiments of fresh and stored seeds are presented in fig. 1 . These data show that fresh seeds have had a high germination capacity of $94,3 \%$. Such percentage can be considered as a original level for comparison with the others obtained during the tests with the stored seeds.

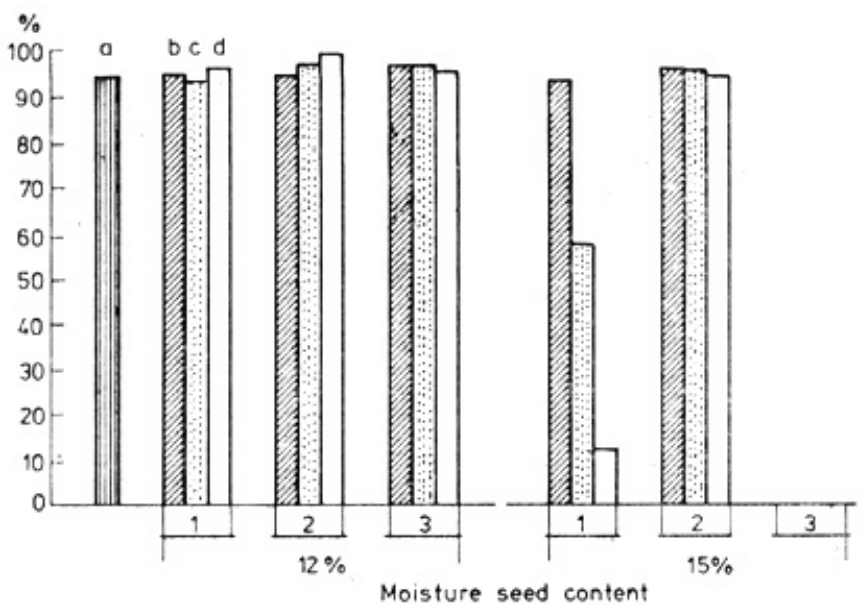

Fig. 1. Results of germination of spring wheat seeds var. 'Kolibri' $(\%)$ $a-$ fresh seeds, $b-d$ - seeds stored 6,12 , and 18 months, respectively

1 - labile temperature of storage, $2-0^{\circ} \mathrm{C}$ temperature of storage, $3-25-30^{\circ} \mathrm{C}$ temperature of storage

Seeds stored at $12 \%$ M.C. and at the different temperature degrees, and those stored at $15 \%$ M.C. and $0{ }^{\circ} \mathrm{C}$ retained a germination power relatively close to the original level along the passage of storage time. On the other hand, seeds stored at $15 \%$ M.C. and labile temperature rapidly decreased in their viability within the second and third period of storage, while those stored at high temperature degree of $25-30^{\circ} \mathrm{C}$ lost $100 \%$ of their germination power within the first six months.

It was observed during these experiments that the latter seeds revealed brown discoloration.

Mycological analysis of seeds. Results of mycological analysis of seeds are presented in Table 1 and Fig 2 to 5 . A total of 2852 colonies were isolated. 39 fungus species were recovered throughout this analysis (Table 1). 
Fresh seed-borne fungi. Fungal analysis of fresh seeds (analysis I) showed complete surface contamination of such seeds; $19 \%$ of them were internally invaded with fungal flora. Alternaria alternata was the most common isolated species. Other species of fungi, namely Aspergillus flavus, Helminthosporium triseptatum, Ulocladium atrum, Sclerotinia sp., Mucor sp., and Fusarium sp. were recovered in smaller amounts.

Stored seed-borne fungi. Seeds stored at $12 \%$ moisture content. A total of 1074 and 192 fungal colonies were obtained from the non disinfected and disinfected seeds, respectively (Table 1). Distribution of these amounts (Fig. 2) indicate that percent of surface and internal contamination of seeds was increased after their storage

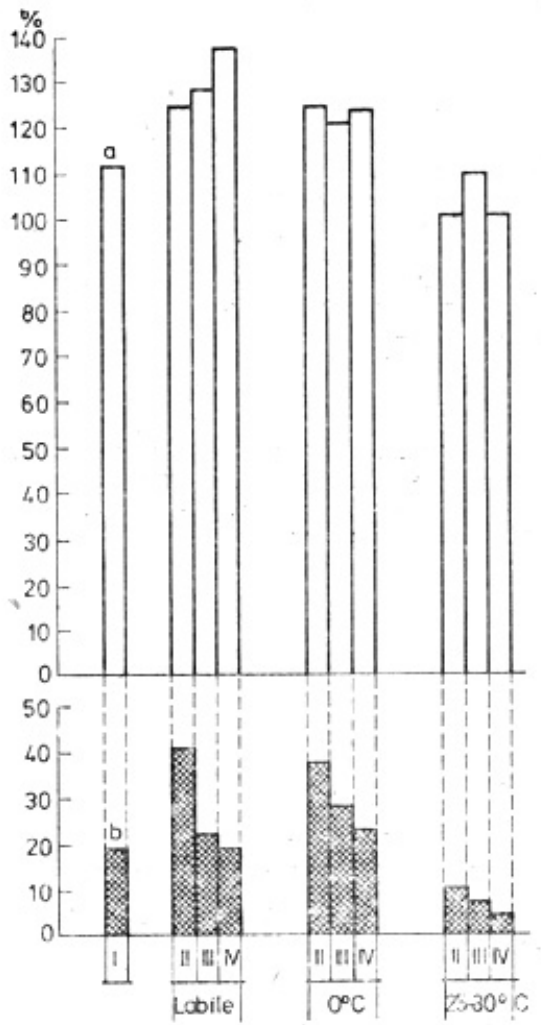

Fig. 2. Effect of temperature and time of storage on the number of fungal colonies isolated from seeds stored at $12 \%$ moisture content

a - non disinfected seeds, b - disinfected seeds, I to IV - signs of mycological analysis after 0 (fresh), 6, 12, and 18 months of storage; labile, $0^{\circ}$ and $25-30^{\circ} \mathrm{C}$ temperature of storage 
at labile and $0^{\circ} \mathrm{C}$. Such increase was relatively lacking at $25-30^{\circ} \mathrm{C}$ Alternaria alternata and Aspergillus flavus were the most numerous isolated species (Table 1). The data illustrated in Fig. 3 revealed the development and retention of Alternaria alternata on and in the seeds at labile and $0^{\circ} \mathrm{C}$. Such retention was reduced to about $50 \%$ after storage the seeds at $25-30^{\circ} \mathrm{C}$ in comparison with the original level. Along the passage of storage time, at all these above temperatures degrees, slight decrease in number of colonies obtained was observed. On the other hand, Aspergillus flavus was only recovered from the non disinfected seeds. Many more isolated colonies were obtaned from seeds stored at $25-30^{\circ} \mathrm{C}$. Furthermore, the number of colonies increased with the time

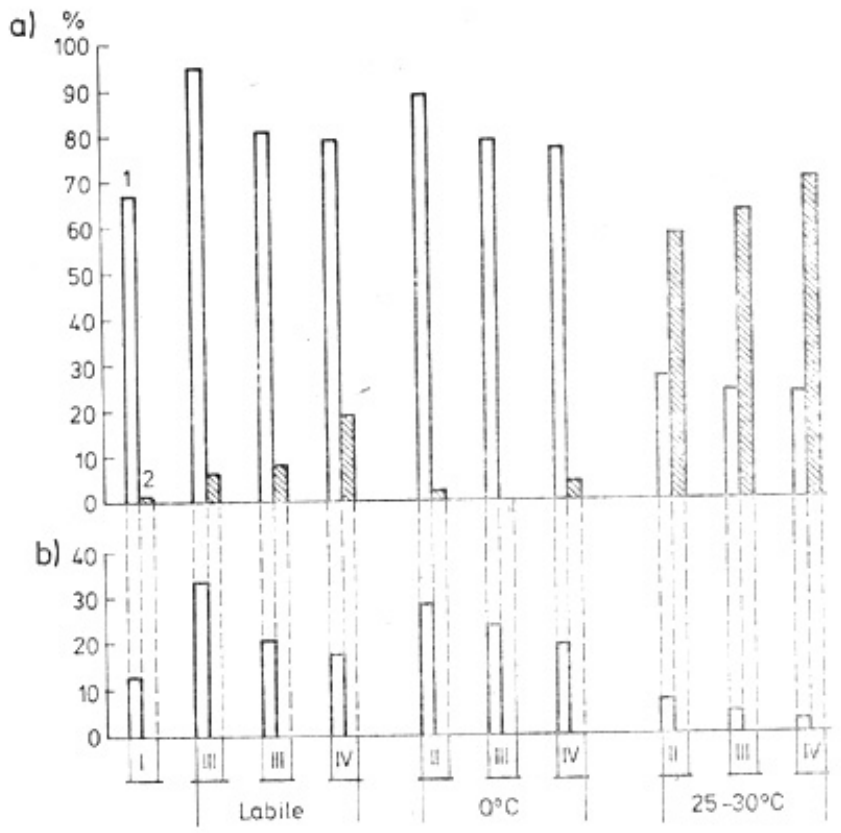

Fig. 3. Exfect of temperature and time of storage on number of colonies of Alternaria alternata (1) and Aspergillus flavus (2) isolated from seeds stored at $12 \%$ moisture content

a - non disinfected seeds, $b-$ disinfected seeds

of storage. The highest percent of seed contamination with Alternaria alternata was recorded after 6 months in storage at labile temperatures (analysis II). Aspergillus flavus gave the same result after 18 months at $15-20^{\circ}$ (analysis IV).

Seeds stored at $15 \%$ moisture content. A total of 1014 and 309 fungal 
colonies were isolated from the non disinfected and disinfected seeds, respectively. The data presented in Fig. 4 revealed complete surface contamination of seeds after storage. The seeds were mainly covered

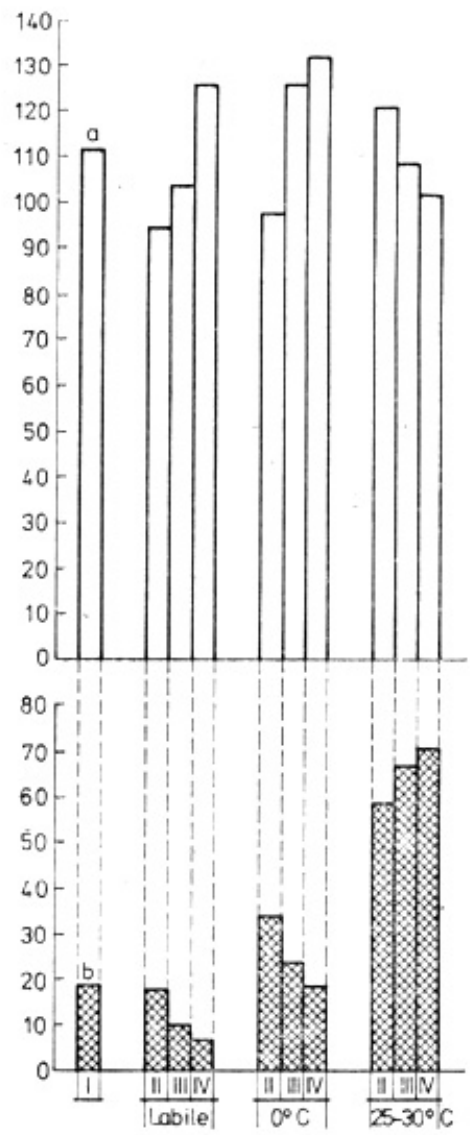

Fig. 4. Effect of temperature and time of storage on the number of fungal colonies isolated from seeds stored at $15 \%$ moisture content

$a$ - non disinfected seeds, $b$ - disinfected seeds

on the surface with fungal flora after 18 months in storage at labile temperatures and $0^{\circ} \mathrm{C}$. On the other hand, percent of internal contamination was greatly increased at $25-30^{\circ} \mathrm{C}$ in contrast with that observed at labile temperatures and $0^{\circ} \mathrm{C}$. Although $71 \%$ of seeds were internally invaded after 18 months at $25-30^{\circ} \mathrm{C}$, only 7 and $19 \%$ were invaded at labile temperatures and $0^{\circ} \mathrm{C}$, respectively. 
Alternaria alternata and different species of Aspergillus and Penicillium genera were most commonly isolated (Table 1).

Four Aspergillus species, namely A. flavus, A. candidus, A. repens and $A$. amstelodami were commonly recovered. At labile temperatures the seeds were externally invaded with $A$. flavus and in part with A. repens (Fig. 5). The latter deeply invaded a small percent of seeds within the second and third period of storage.

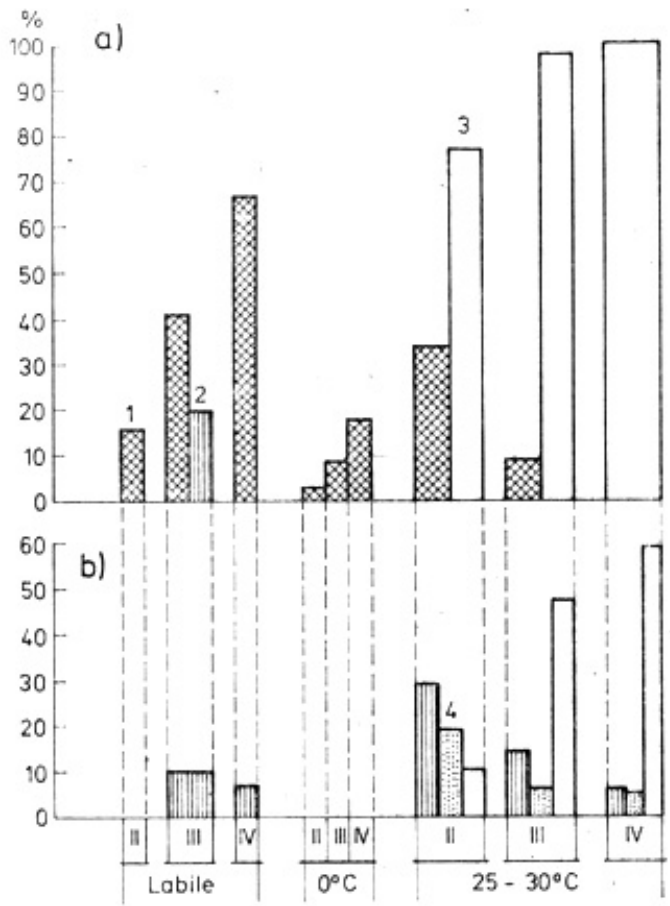

Fig. 5. Effect of temperature and time of storage on the number of colonies of each of Aspergillus flavus (1), A, repens (2), A. candidus (3), and A. amstelodami (4) which isolated from seeds stored at $15 \%$ moisture content $a-$ non disinfected seeds, $b-$ disinfected seeds

At $0^{\circ} \mathrm{C}$ of storage, small percent of seeds shoved external contamination with $A$. flavus. That percent was 3 after 6 months in storage. Afterwards, it increased to $18 \%$ after 18 months. Percent of internal invasion with Aspergillus spp. was zero at this above temperature. At high storage temperatures of $25-30^{\circ} \mathrm{C}$, the seeds were covered on the surface with $A$. flavus and $A$. candidus. The latter species in addition to $A$. repens and $A$. amstelodami were located deeper. During 


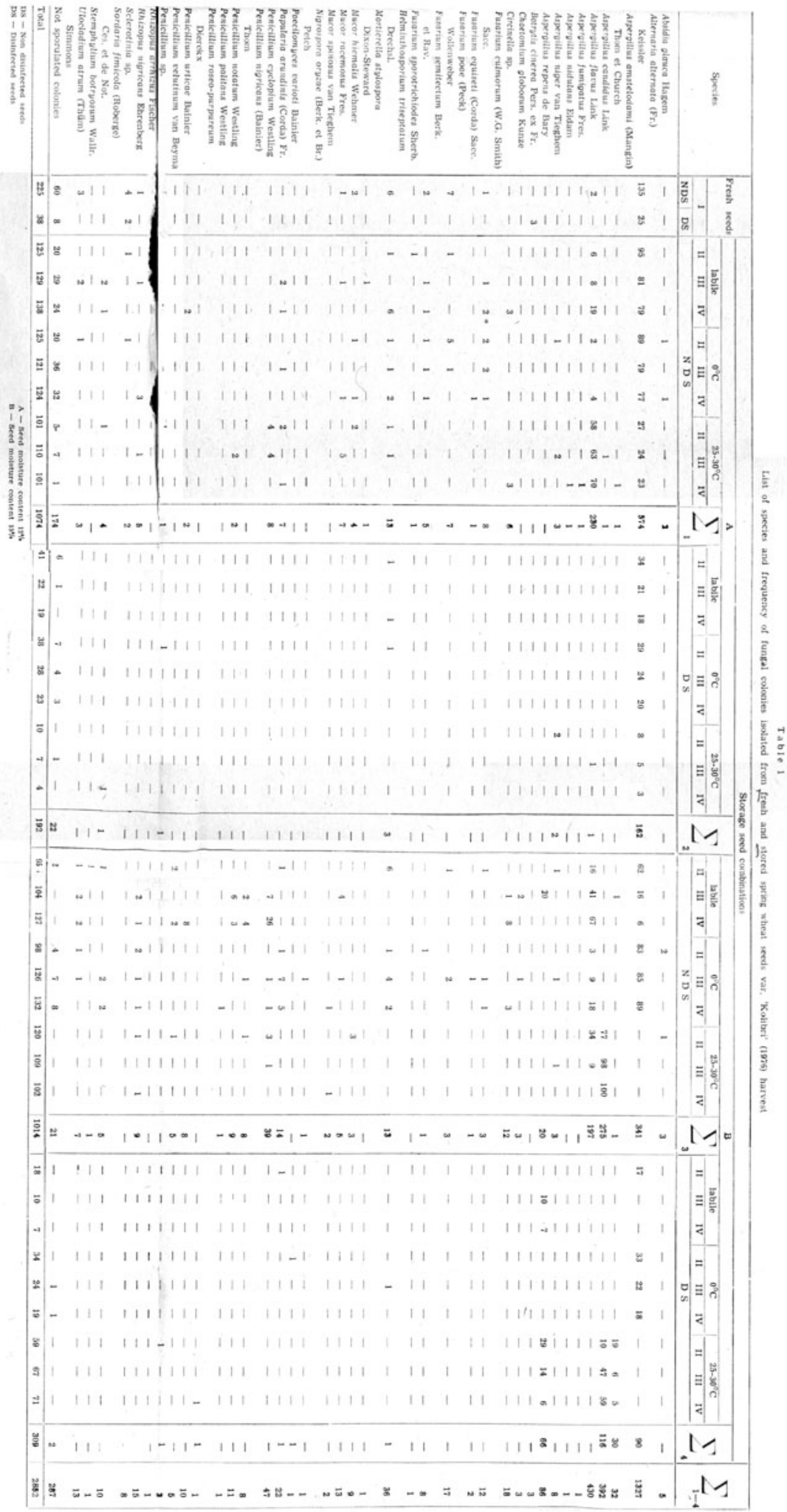


storage time $A$. candidus developed much more externally and internally as the other species decreased. This result was markedly observed after 18 months in storage as $100 \%$ of seeds were contaminated on the surface with $A$. candidus. Percent of deeper invasion with that fungus after the same period was 59 .

Throughout the mycological analysis of the stored seeds five Fusarium species were sporadically isolated (F. culmorum,. F. poae, F. equiseti, F. semitecum and $F$. sporotrichioides).

Pot experiments and mycological analysis of plants

Pot experiments. Results obtained (Table 2) indicate that the percent of seedlings emergence was distinctly higher in non sterilized soil $(a, b)$. Furthermore, the percent of emergence of the seedlings was

Table 2

Percent of seedlings emerging 15 days after sowing stored seeds, at 24 traeatments

\begin{tabular}{|c|c|rrrr|}
\hline $\begin{array}{c}\text { Storage seed } \\
\begin{array}{c}\text { moisture } \\
\text { content } \\
(\%)\end{array}\end{array}$ & $\begin{array}{c}\text { combination } \\
\left({ }^{\circ} \mathrm{C}\right)\end{array}$ & \multicolumn{3}{|c|}{ Sowing conditions } \\
\hline & & \multicolumn{4}{c|}{$\begin{array}{c}\text { of emerging } \\
\text { seedlings }\end{array}$} \\
\cline { 2 - 6 } 12 & a & b & c & d \\
\cline { 2 - 6 } & labile & 86 & 79 & 84 & 72 \\
& 0 & 91 & 71 & 81 & 69 \\
& $25-30$ & 88 & 74 & 76 & 64 \\
\hline 15 & $1 a b i l e$ & 91 & 63 & 78 & 60 \\
& 0 & 87 & 50 & 82 & 75 \\
& $25-30$ & 0 & 0 & 0 & 0 \\
\hline
\end{tabular}

a - Non disinfected seeds sown in non steritized soil

b - Disinfected seeds sown in non sterilized soil

c - Non disinfected seeds sown in sterilized soll

a - Disinfected seeds sown in sterilized soil

high those developed from non disinfected seeds $(a, c)$; that percent was lesser after disinfection treatments $(b, d)$. The highest percent of emergence $(91 \%)$ was recorded at two treatments of sowing seeds stored at $12 \%$ M.C. and $0^{\circ} \mathrm{C}$, as well as at $15 \%$ M.C. and labile temperature. Plantation in non sterilized soil lead, in general, to obtain plants with high values of toatal mean length of stems and ears (Table 3). That result was observed on plants developed from disinfected seeds. In the 


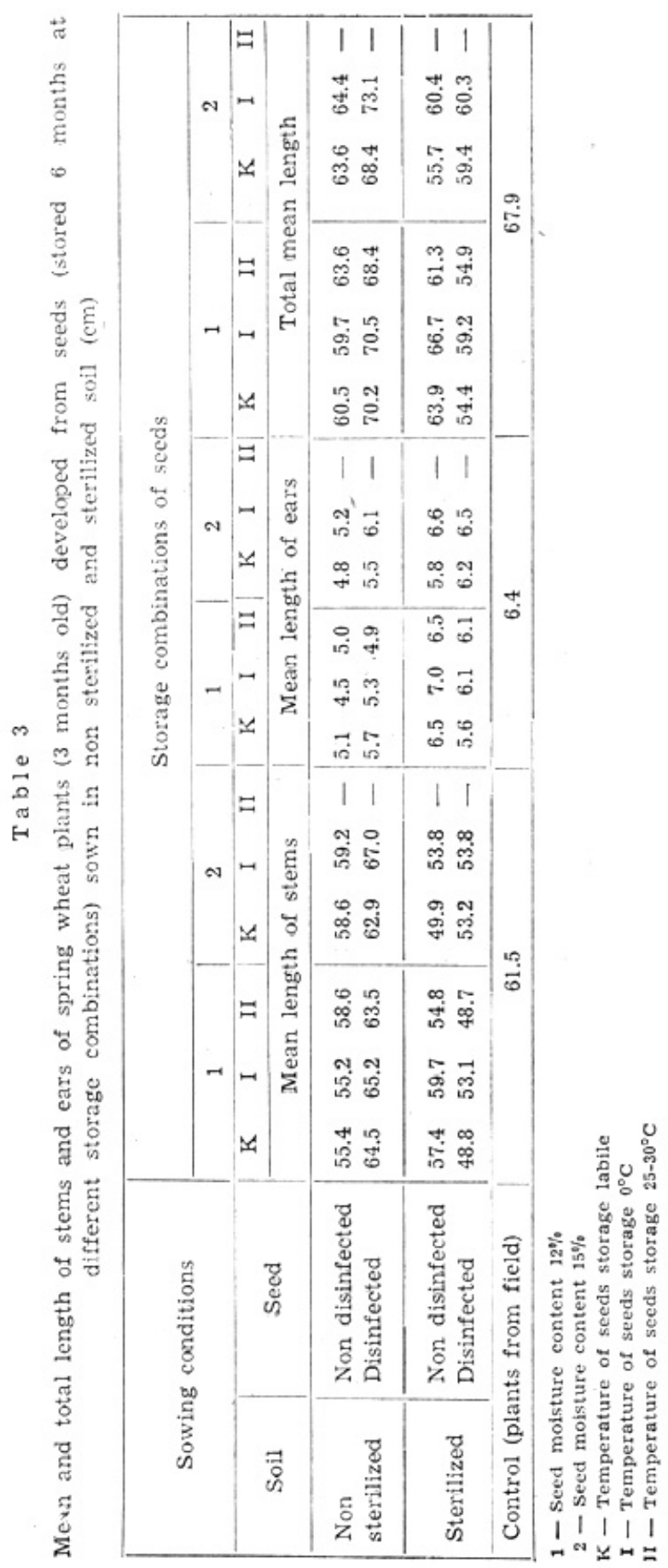




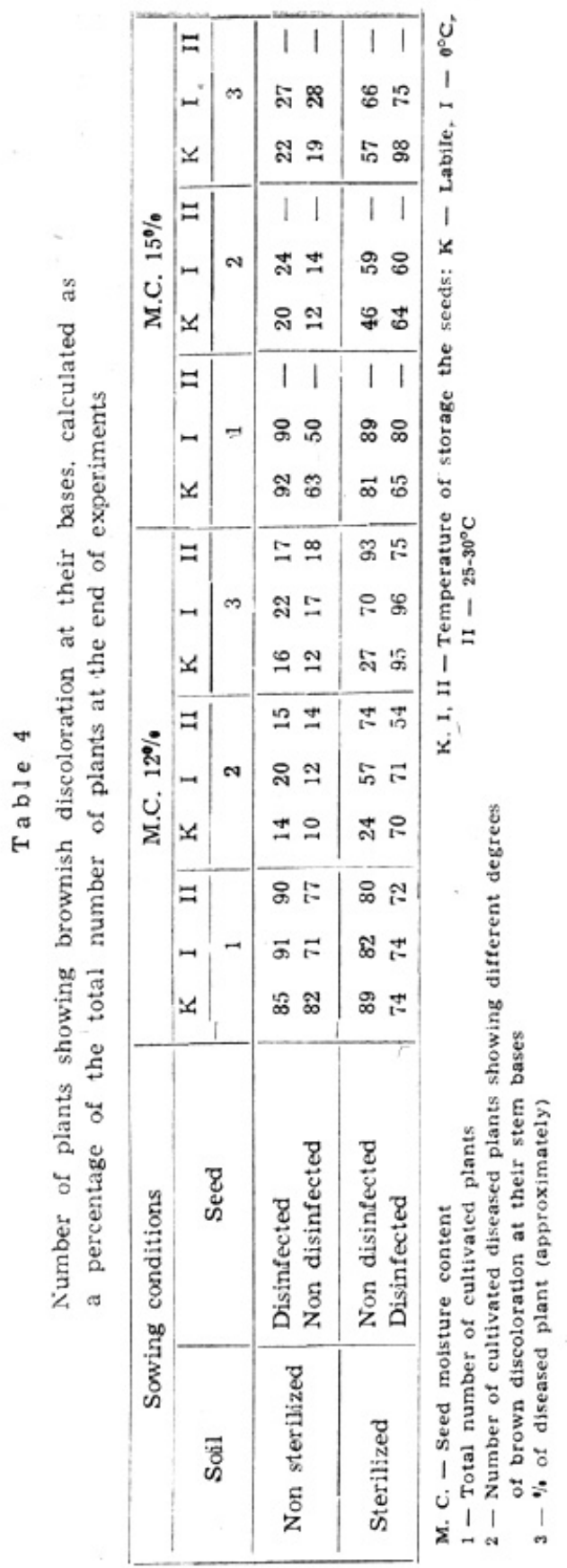




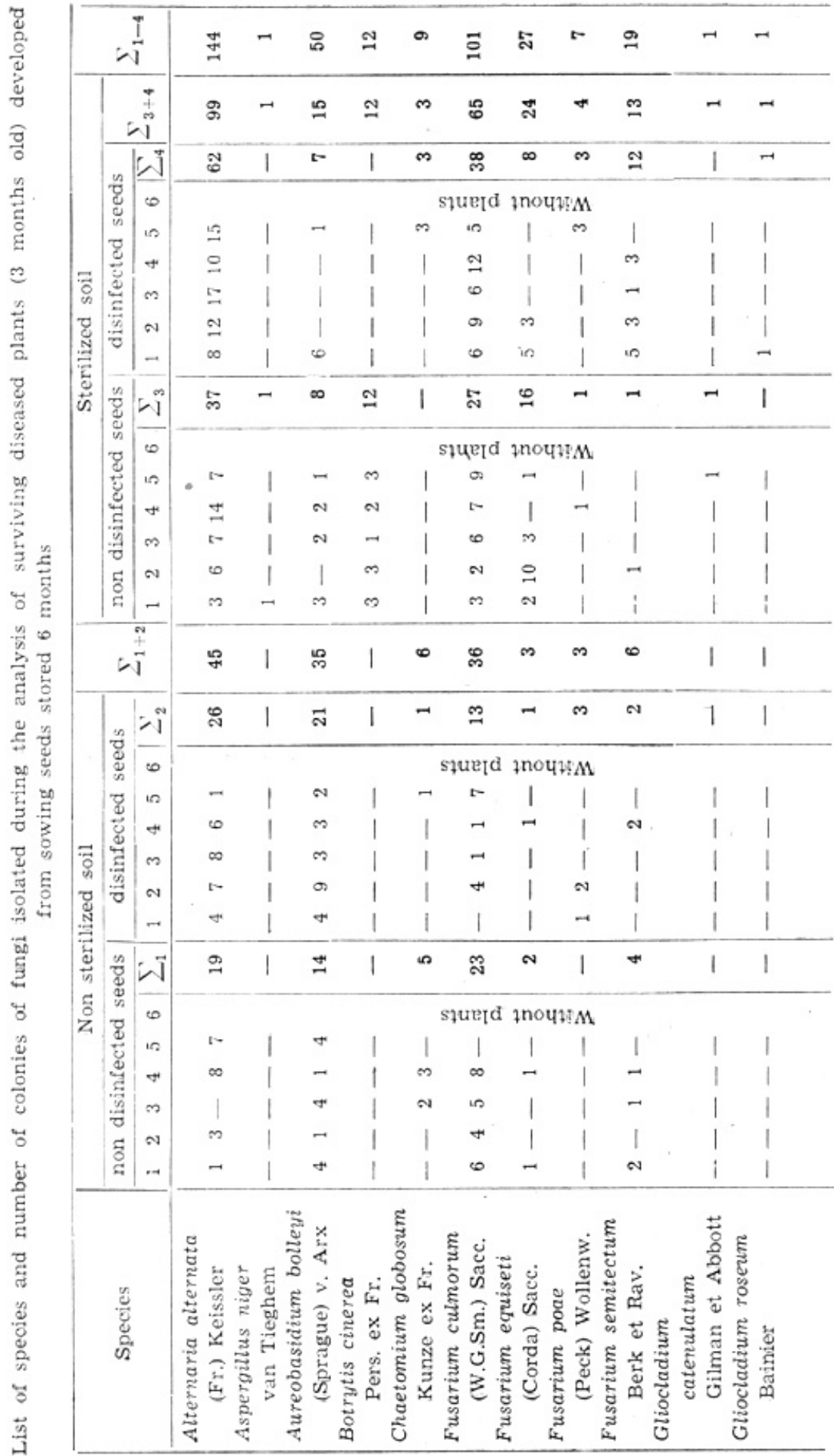




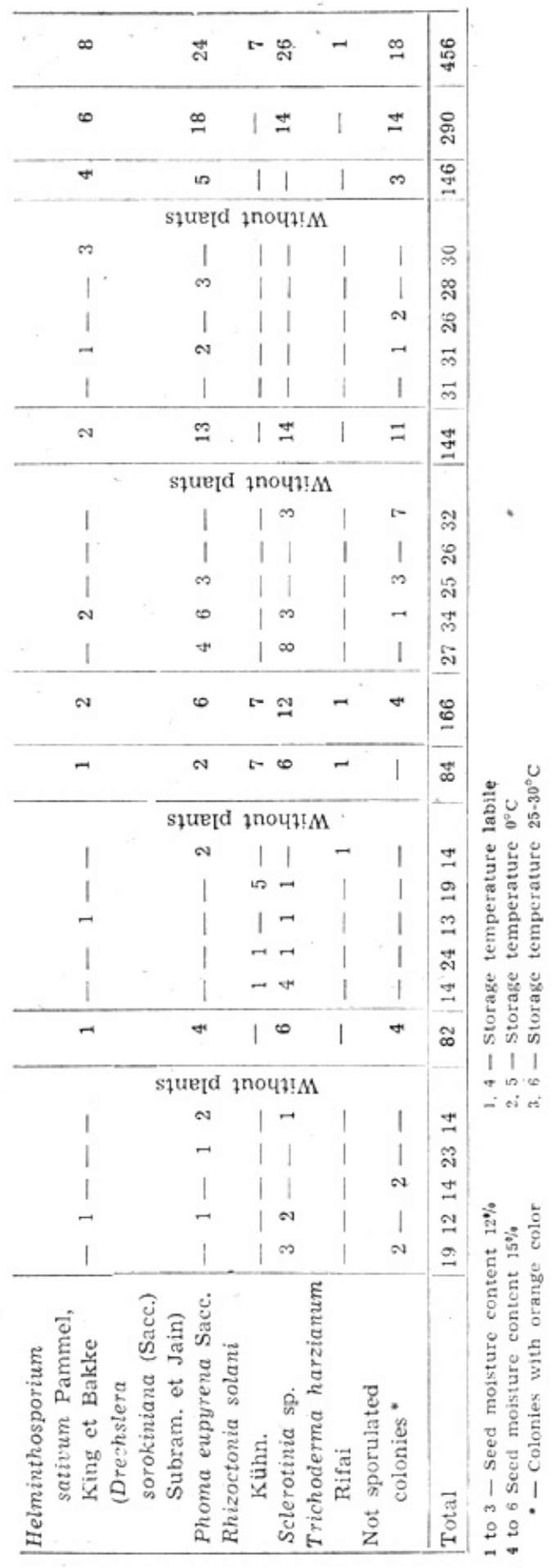


relation of storage seed condition, the data given in the above table indicate that all the plants developed from seeds stored at $0^{\circ} \mathrm{C}$ reached high values of mean length of stems and or ears.

On the other hand plantation in the sterilized soil led to an increase in the percentage of piants showing symptoms of foot rot disease (Table 4). That percent was lower for plants grown in non sterilize soil.

Mycological analysis of plants. 456 fungal colonies were isolated throughout these experiments. 16 different species of fungi were recorvered (Table 5). That high percentage $\left(63,6^{0} \%\right.$ ) of the above total number of colonies was obtained during the fungal analysis of plants grown in sterilized soil. Among the different isolated species of fungi Alternaria aiternata and Fusarium spp. were most-numerous ( $F$. culmorum, $F$. equiseti, $F$. poae, $F$. semitectum). Many colonies of the former species were obtained from plants grown in non sterilized soil (Fig. 6). Fewer colonies of Helminthosporium sativum and Rhizoctonia solani (Table 5).

Surface disinfection of the seeds prior to sowing markedly increased the occurrence of A. alternata and Fusarium spp. on plants grown in sterilized soil (Fig. 7).

No distinct results were obtained about the relation of condition of storage of the seeds and the number or kinds of isolated fungal species (Table 5).

Biological experiments. The bictic effect of fungal communities of seeds. All the fungal communities isolated from non di-

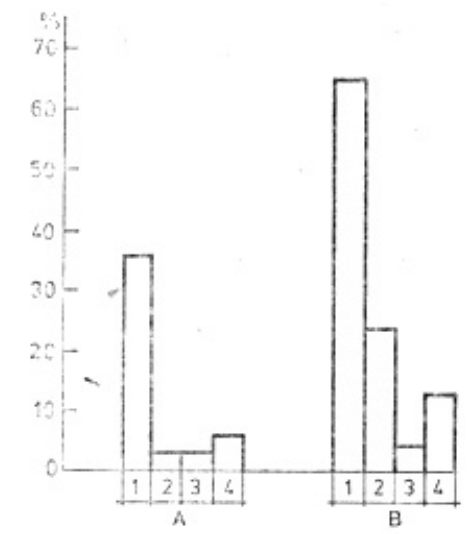

Fig. 6. Number of colonies of four Fusarium species isolated from bases of diseased plants

$A-$ plents grew in non sterilized soil, $B-$ plants grew in sterilized soll; $1-F$. culmorum, $2-F$. equiseti, $3-F$. poae, $4-F$. semitectum 


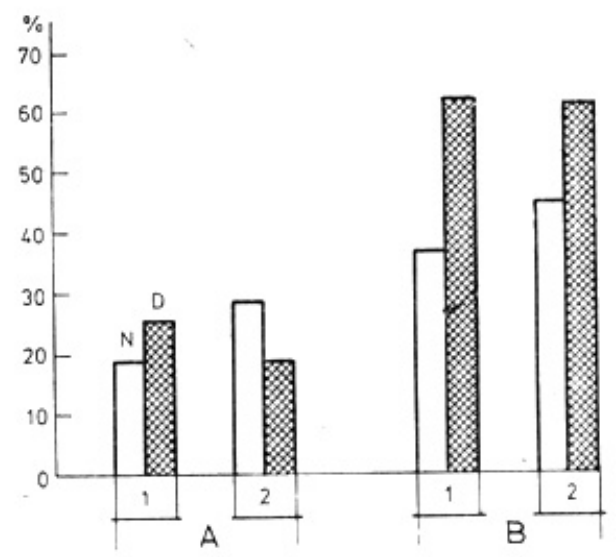

Fig. 7. Number of colonies of Alternaria alternata (1) and Fusarium spp. (2) isolated from bases of diseased plants

A - plants grew in non sterilized soil, $B$ - plants grew in sterilized soll; $N$ - plants developed from non disinfected seeds, $D$ - plants developed from disinfected seeds

sinfected fresh and stored seeds throughout the analysis I to IV (Table 1) were tested for their biotic effect on $F$. culmorum, $F$. poae and $F$. equiseti. Nineteen communities of fungi were tested. All fungal species, except the selected pathogens, within each fungal community were individually tested for their biotic effect on each pathogen. Data of summary biotic effect of each community is shown in Table 6. On the basis of these data the following conclusions were drawn.

a - negative values of summary biotic effect were defined for fungal communities isolated from fresh seeds. High values were recorded on both of $F$. culmorum and $F$. poae. Lesser values were recorded on F. equiseti.

b-after storage of the seeds, all the isolated fungal communities in general, had the same above trend. High values of summary biotic effect were recorded for fungal communities isolated from seeds stored at $12 \%$ moisture content and either labil temepratures or $0^{\circ} \mathrm{C}$. Similar results were obtained for fungal communities isolated from seeds stored at $15 \%$ moisture content and $25-30^{\circ} \mathrm{C}$. No great differences were obtained for the relation between time of storage and values calculated. These results demonstrate that either fresh or stored seed-borne fungi do not limit the development of each of the pathogens mentioned above.

$\mathrm{c}$ - communities of fungi isolated from seeds stored at $12 \%$ moisture content and $25-30^{\circ} \mathrm{C}$ gave positive values of the biotic effect on Fusarium 


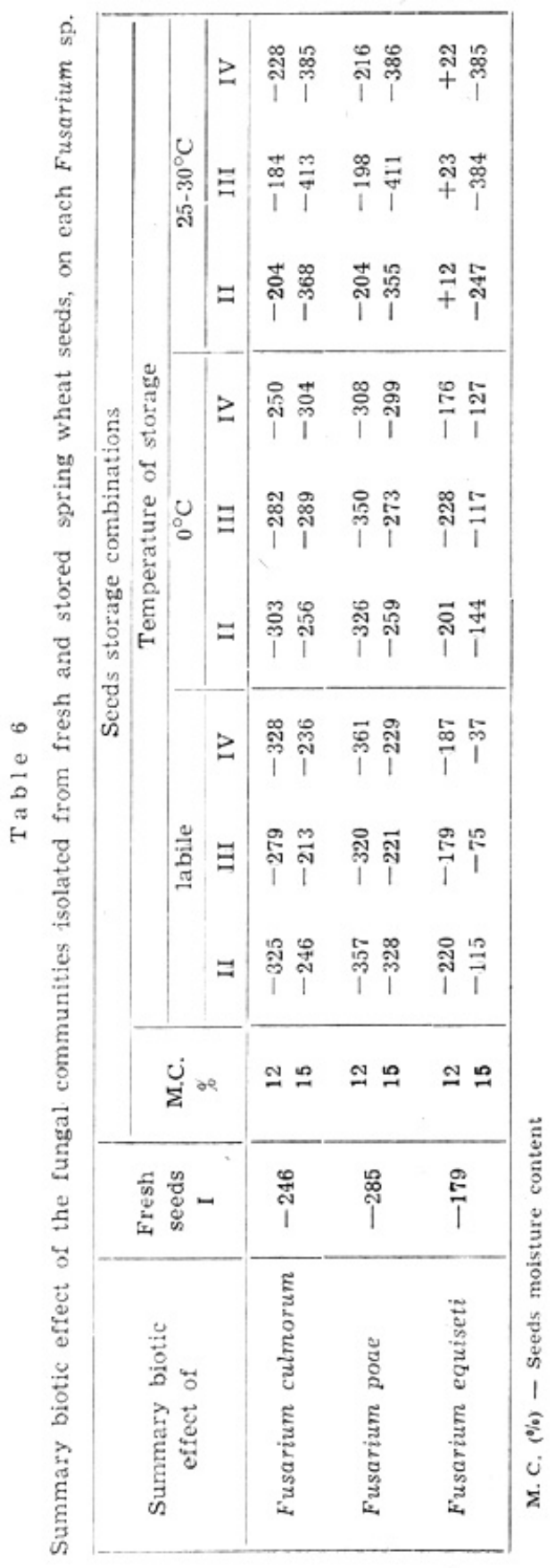


Table 7

Summary bictic effect of fungal communities isclated from diseased plants dęveloped from seeds, stored at $12 \%$ mo'sture content and various temperature, sown at different cunditions

\begin{tabular}{|c|c|c|c|c|c|}
\hline \multirow{2}{*}{$\begin{array}{c}\text { Summary biotic } \\
\text { effect on: }\end{array}$} & \multirow{2}{*}{$\begin{array}{c}\text { Temperature } \\
\text { of storage }\end{array}$} & \multicolumn{4}{|c|}{ Sowing conditions } \\
\hline & & a & b & c & d \\
\hline \multirow{3}{*}{ Fusarium culmorum } & labile & -31 & -32 & -42 & -65 \\
\hline & $0^{\circ} \mathrm{C}$ & -20 & -50 & -43 & -56 \\
\hline & $25-30^{\circ} \mathrm{C}$ & -22 & -34 & -37 & -57 \\
\hline \multirow{3}{*}{ Fusarium poae } & labile & -12 & -4 & +20 & -58 \\
\hline & $0^{\circ} \mathrm{C}$ & -4 & -43 & -16 & -53 \\
\hline & $25-30^{\circ} \mathrm{C}$ & -25 & -32 & -42 & -60 \\
\hline \multirow{3}{*}{ Fusarium equiseti } & labile & 0 & +4 & +31 & -30 \\
\hline & $0^{\circ} \mathrm{C}$ & -2 & -19 & -3 & -35 \\
\hline & $25-30^{\circ} \mathrm{C}$ & -5 & -19 & -25 & -39 \\
\hline \multirow{3}{*}{ Rhizoctonia solani } & labile & -19 & -16 & +2 & -60 \\
\hline & $0^{\circ} \mathrm{C}$ & -13 & -46 & -21 & -55 \\
\hline & $25-30^{\circ} \mathrm{C}$ & -15 & -35 & -36 & -58 \\
\hline
\end{tabular}

Ta ble 8

Summary biotic effect of fungal communities isolated from diseased plants developed from seeds, stored at $15 \%$ moistu.e content and various temperature, sown at different conditions

\begin{tabular}{|c|c|c|c|c|c|}
\hline \multirow{2}{*}{$\begin{array}{l}\text { Summary biotic } \\
\text { effect of: }\end{array}$} & \multirow{2}{*}{$\begin{array}{l}\text { Temperature } \\
\text { of storage }\end{array}$} & \multicolumn{4}{|c|}{ Sowing conditions } \\
\hline & & a & b & c & d \\
\hline Fusarium culmorum & $\begin{array}{l}\text { labile } \\
0^{\circ} \mathrm{C}\end{array}$ & $\begin{array}{l}-40 \\
-41\end{array}$ & $\begin{array}{l}-37 \\
-11\end{array}$ & $\begin{array}{l}-44 \\
-34\end{array}$ & $\begin{array}{l}-51 \\
-57\end{array}$ \\
\hline Fusarium poae & $\begin{array}{l}\text { labile } \\
0^{\circ} \mathrm{C}\end{array}$ & $\begin{array}{l}-39 \\
-34\end{array}$ & $\begin{array}{l}-28 \\
-11\end{array}$ & $\begin{array}{l}-42 \\
-22\end{array}$ & $\begin{array}{l}-48 \\
-51\end{array}$ \\
\hline Fusarium equiseti & $\begin{array}{l}\text { labile } \\
0^{\circ} \mathrm{C}\end{array}$ & $\begin{array}{l}-15 \\
-20\end{array}$ & $\begin{array}{r}-13 \\
-1\end{array}$ & $\begin{array}{r}-18 \\
-2\end{array}$ & $\begin{array}{l}-32 \\
-25\end{array}$ \\
\hline Rhizoctonia solani & $\begin{array}{c}\text { labile } \\
0^{\circ} \mathrm{C}\end{array}$ & $\begin{array}{l}-27 \\
-37\end{array}$ & $\begin{array}{r}-31 \\
-5\end{array}$ & $\begin{array}{l}-36 \\
-17\end{array}$ & $\begin{array}{l}-48 \\
-48\end{array}$ \\
\hline
\end{tabular}

equiseti only. These positive values increased with time of storage. Thus, it may be concluded that $F$. equiset $i$ under these storage conditions can be inhibited by the other associated fungal species.

The biotic effect of fungal communities of plants. All fungal communities isolated from plants (Table 5) were tested for their biotic effect on of $F$. culmorum, $F$. poae, $F$. equiseti and Rhizoctonia solani. 
All species, except the pathogens mentioned, within each community were individually tested biotic effect.

Data of summary biotic effect are presented in Tables 7 and 8 . These data show the followings:

1 -negative value of biotic effect were found for all the communities in general. This result demonstrates the possibility of development of each of these pathogens without limit action of the associated fungal species;

2 - the above result was distinctly observed in case of fungal communities isolated from plants grown in sterilized soil;

3 - the highest values of summary biotic effect were recorded, throughout these experiments, for $F$. culmorum while the lower. lesser ones against values were obtained for $F$, equiseti;

4 - no definite results were obtained for the connection of the different conditions of storage the seeds to be used for sowing and data obtained of the summary biotic effects.

\section{Pathogenicity experiments}

Results of these experiments demonstrate that colonies of Fusarium culmor:m brought about fast infection and death at 10-12 days old of all seedlings emerging. Severity of attack ranged from total destruction of the young plumule through noticeable browning of the coleoptile and lower leaf sheaths. The mean length of shoots was relatively lower at treatments than at control plants. At both, the values recorded were found to be unaffected by the percentage of moisture content of the seeds (Table 9).

The colonies of $F$. poae did not bring about any symptoms of disease at the different stages of these experiments. No great differences in mean length of stems and roots within and between the treatments, and/or control treatments (Table 10).

Reisolation experiments of pathogens from the seedlings (12 days old) and plants ( 3 months old) showed the following results:

1 - Fusarium culmorum was reisolated, within 4 days of incubation from all the seedlings ( 6 seedlings).

$2-F$, poae and ten other fungal species were isolated from all cultivated plants (Table 11); $50 \%$ of total isolated number of colonies belong to three species of Fusarium genus. Among these species F. culmorum presented the highest number of colonies (10 colonies) treatment 2B (Table 11). 
Table 9

Effect of the antificial infection in vitro, with Fusarium culmorum, on length of shoots of spring wheat seedlings (12 days old)

\begin{tabular}{|c|c|c|c|c|}
\hline \multirow{3}{*}{$\begin{array}{l}\text { Number } \\
\text { of tube }\end{array}$} & \multicolumn{4}{|c|}{ Length of shoots $(\mathrm{cm})$} \\
\hline & \multicolumn{2}{|c|}{ Treatments } & \multicolumn{2}{|c|}{ Control-treatments } \\
\hline & 1 & 2 & 1 & 2 \\
\hline 1 & 6.0 & 8.0 & 11.0 & 8.5 \\
\hline 2 & 10.5 & 10.5 & 12.0 & 12.0 \\
\hline 3 & 11.5 & 9.0 & 14.0 & 13.0 \\
\hline 4 & 7.5 & 12.0 & 13.0 & 7.0 \\
\hline 5 & 11.0 & 6.5 & 12.5 & 12.0 \\
\hline 6 & 8.0 & 9.5 & 15.0 & 13.0 \\
\hline 7 & 10.0 & 10.5 & 11.0 & 13.5 \\
\hline 8 & 10.5 & 8.0 & 10.0 & 10.5 \\
\hline 9 & 5.0 & 10.0 & 10.5 & 13.5 \\
\hline 10 & 12.0 & 9.5 & 13.0 & 12.0 \\
\hline 11 & 9.5 & 10.5 & 12,0 & 8.0 \\
\hline 12 & 11.0 & 9.5 & 11.0 & 11.0 \\
\hline 13 & 9.5 & 7.0 & 10.5 & 12.5 \\
\hline 14 & 10.0 & 8.0 & 10.0 & 13.0 \\
\hline 15 & 7.0 & 8.5 & 11.0 & 14.0 \\
\hline 16 & 8.0 & 8.0 & 13.5 & 12.0 \\
\hline 17 & 6.5 & 11.0 & 12.0 & 9.0 \\
\hline 18 & 9.5 & 7.0 & 11.0 & 10.0 \\
\hline 19 & 8.0 & 10.0 & 14.0 & 11.5 \\
\hline 20 & 11.0 & 6.5 & 12.0 & 14.0 \\
\hline 21 & 8.0 & 11.0 & 11.0 & 13.0 \\
\hline 22 & 11.5 & 7.5 & 10.5 & 10.0 \\
\hline 23 & 5.5 & 5.5 & 9.5 & 9.5 \\
\hline 24 & 10.5 & 6.5 & 10.5 & 12.0 \\
\hline 25 & 9.0 & 9.5 & 12.0 & 11.0 \\
\hline $\begin{array}{l}\text { Mean } \\
\text { length }\end{array}$ & 9.06 & 8.78 & 11.7 & 11.42 \\
\hline
\end{tabular}

1 and 2 - Seedlings developed from seeds stored at 12 and $15 \%$ moisture content respetively, and $0^{\circ} \mathrm{C}$ for 18 months

\section{DISCUSSION}

The germination experiments revealed rapid loss in germination capacity of seeds stored at $15 \%$ M.C. and either labile temperatures or $25-30^{\circ} \mathrm{C}$. This result showed the important role of storage conditions in enabling certain fungal pathogens to invade the seeds and bring about severe deterioration of their embryons. Such deterioration was not observed at the other conditions of storage. 
Table 10

Effect of artificial infection of spring wheat seciling with Fusarium poae, on the mean length of stems and roots of the developing plants

( 3 monhs old) grown in soil from the field

\begin{tabular}{|c|c|c|c|c|c|c|c|c|}
\hline \multirow{3}{*}{$\begin{array}{c}\text { Mean } \\
\text { length } \\
\text { of }(\mathrm{cm})\end{array}$} & \multicolumn{4}{|c|}{ Treatments } & \multicolumn{4}{|c|}{ Control-treatments } \\
\hline & \multicolumn{2}{|c|}{1} & \multicolumn{2}{|c|}{2} & \multicolumn{2}{|c|}{1} & \multicolumn{2}{|c|}{2} \\
\hline & A & B & A & B & A & B & A & B \\
\hline Stems & 19.2 & 19.8 & 19.8 & 20.7 & 18.9 & 18.8 & 20.6 & 18.9 \\
\hline Roots & 25.6 & 29.0 & 28.9 & 24.3 & 24.8 & 28,1 & 29.0 & 27.4 \\
\hline
\end{tabular}

1, 2 - Plants developed from seeds stored at 12 , and $15 \%$ respectively

A, B - Plants grown in non sterilized soil and sterilized soil respectively, during the second stage of the experiments

$\mathrm{T}$ a ble 11

List of species and number of colonies of fungi isolated from bases of stems of spring wheat plants ( 3 months old) grown in soil from field and which developed after artificially infection with Fusarium poae

\begin{tabular}{|c|c|c|c|c|c|c|c|c|}
\hline \multirow{3}{*}{ Species } & \multicolumn{3}{|c|}{ Treatments } & \multicolumn{4}{|c|}{$\begin{array}{l}\text { Control- } \\
\text { treatments }\end{array}$} & \multirow{3}{*}{$\underset{\stackrel{\vec{J}}{0}}{\mathrm{H}}$} \\
\hline & 1 & \multicolumn{2}{|c|}{2} & \multicolumn{2}{|c|}{1} & \multicolumn{2}{|c|}{2} & \\
\hline & A B & A & $\mathrm{B}$ & $\mathrm{A}$ & $\mathrm{B}$ & A & $\mathrm{B}$ & \\
\hline Altermaria alternata (Fr.) & & & & & & & & \\
\hline Keissler & 1 & 2 & - & 1 & 1 & - & - & 6 \\
\hline Acremonium strictum W. Gams & 2 & - & - & - & - & - & - & 3 \\
\hline Aspergillus repens de Bary & -1 & & - & - & - & & - & 4 \\
\hline $\begin{array}{l}\text { Fusarium avenaceum } \\
\text { (Corda ex Fr.) Sacc. } \\
\text { Fusarium culmorum (W. G. Sm.) }\end{array}$ & -- & 3 & 4 & - & - & - & - & 7 \\
\hline Sacc. & -- & - & 10 & - & - & - & - & 10 \\
\hline Fusarium poae (Peck) Wollenw. & -- & 4 & - & - & - & - & - & 4 \\
\hline Penicillium cyclopium Westling & -- & 1 & - & - & 一 & - & - & 1 \\
\hline Penicillium puberulum Bainier & - - & - & - & - & 1 & - & - & 1 \\
\hline Penicillium claviforme Bainier & - & - & - & 1 & - & - & - & 1 \\
\hline Phoma eupyrena Sacc. & -1 & - & - & - & - & - & - & 1 \\
\hline Sclerotinia sp. & -- & - & - & 2 & - & - & - & 2 \\
\hline Total & 34 & 10 & 14 & 4 & 2 & 3 & - & 40 \\
\hline
\end{tabular}

1. 2 - Plants developed from seeds stoted at 12. and $15 \%$ moisture content, respectively A, B - Plants grown in non sterilized and sterilized soil during the second part of patho genicity experiments

Trials to define the specifity of fungal species associating with either fresh or stored seeds showed marked differences among the isolated fungi. Fresh seeds were completely surface contamined with few species 
belonging to the so called "field fungi". Among them, Alternaria alternata was the most common. The lower percent of isolation of some fungal pathogens, especially those belonging to Fusarium genus, may be attributed to the masking effect of Alternaria alternata in the agar tests as noted by Limonard (1968). The results of fungal analysis of fresh seeds showed also that small percent of them were internally invaded, mainly with $A$. alternata. Such invasion had no effect on the bealth state of the seeds. This result may confirm that obtained by Noble et al. (1958). However, Huguelet and Kiesling (1973), and Neergaard (1945) reported the pathological features of Alternaria alternate on certain plants.

During storage of the seeds, the conditions of storage, mainly temperature, affected the specifity of fungi. At $12 \%$ M.C. and labile temperatures and $0^{\circ} \mathrm{C}$ well as at $15 \%$ M.C. and $0^{\circ} \mathrm{C}$. A, alternata remained attached to the seeds. The time of storage had no great effect. Persistence of A. alternata on and in the stored seeds may be attributed to some factors, namely temperature of storage, the ability of that fungus to survive for a long time as defined by $\mathrm{M} \mathrm{achacek}$ and $\mathrm{Wa}: 1 \mathrm{ace}$ (1952), and the lack of strong competitors under these storage conditions.

At the other conditions of storage of the seeds, A. alternaria dies out or decreased as other species of fungi developed. These species were from the Aspergillus and Penicillintm genera. At $12 \%$ M.C. and $25-30^{\circ} \mathrm{C}$, surface of seeds were much colonized by $A$, flavus and in part with A. alternata. The development of the former species did not affect the health state of seeds. This result may be incompatible with those obtained hy Lopez and Christensen (1967), and Fields and King (1962) on corn and pea seeds, respectively. The development of A. repens, in part with $A$. flavus and Penicillium spp. on and in the seeds may be affected on the health state of seeds stored at $15 \%$ M.C. and labile. On the other hand, invasion of seeds with storage fungi was markedly observed at $15 \%$ M.C. and $25-30^{\circ} \mathrm{C}$. Four Asprergillus species (A. flavus, $A$. candidus, $A$. repens and $A$. amstelodami) were recovered. The competition factor among these micorganisms lead to much more development of $A$. candidus. The complete lose of germination capacity of seeds after 6 months in storage may be a result of invasion the seeds with these above species, especially $A$. candidus.

The health state of wheat plants in relation to seed-borne fungi was studied with pot experiments. The results show the importance of natural soil and its microflora on the health state of plants. Plantation of wheat in natural soil increased the percent of seedling emergence and highest of plants percent of plants showing foot rot disease was 
low. The latter result may be agree, with that obtained by Col houn and Park (1964). The results obtained showed the role of seed-l orne fungal communities in occurrence the foot rot disease as percent of diseased plant was high in sterilized soil. In connection of conditions of storage of the seeds to the health state of plants. The results indicate that all plants developed from seeds stored at $0^{\circ} \mathrm{C}$ have had a high values of mean length (stem end/or ears). This result agrees, in general, with that obtained by Truszkowska and Urban (1978) on poppy seed-lings.

The mycological analysis of samples of diseased plants pointed out numerous fungal species associated with them. Among these species Fusarium culmorum, F. poae, F. equiseti and Rhizoctonia solani were isolated. The relationship between $F$. culmorum and foot rot disease was extensively studied by many workers, e.g. Col houn et al. (1968), Malalasekera and Tom inson (1968), and Malalasekera et al. (1973). Rhizoctonia solani had been also studied in this relation by Bruehl (1951), and Pokacka and Wojtaszek (1977).

On the basis of frequent isolation of certain Fusarium spp. from both seeds and plants, trials were done to show the interrelations between each of them and other associated species of fungi. These trials were carried out by the series biotic method of $\mathrm{Mank}$ a (1968). the results obtained demonstrate that fungal communities of seeds or plants do not limit, in fseneral, ench of the pathogens tested, including $F$ culmorum. As a result that pathogen can develop and spread from seeds to the stem of a developing plant and bring about symptoms of foot rot disease.

\section{CONCLUSIONS}

1. Mycological analysis of seeds is very important for agricultural practice because they indicate the danger of the pathogenic fungi infection to an important cultivar.

2. Storage of spring wheat seeds at $12 \%$ moisture content and different temperature provided a good health state of seeds for up to 18 months.

3. Seeds stored at $15 \%$ moisture content remained healthy only when stored at $0^{\circ} \mathrm{C}$.

4. Conditions of storage the seeds affected the development of certain seed-borne fungal pathogens.

5. Storage of wheat at either 12 or $15 \%$ M.C. and $0{ }^{\circ} \mathrm{C}$ did not affect the growth and development of plants.

6. Sced-borne fungal community plays a role in occurence foot rot 
disease of wheat, as it did not limit the development of certain fungal pathogens that cause that disease.

7. Seed-borne Fusarium culmorum is a most severe infectious agent of foot rot disease of wheat.

8. Seed-borne $F$. poae is less dangerous to wheat plants than F. culmorum.

9. Both species of Fusarium were not affected by other associating species of fungi (no antagonistic action).

10. Biotic method, first time used here for determination the biotic effect of seed-borne fungal community, appears to be very promising for the further similar investigations.

I am greatly indebted to Professor dr Wanda Truszkow sk a for suggesting the problem, for guidance, and for continued help and criticism during the course of this work.

The author wishes to acknowledge more specifically the helpful assistance and encouraging interest of all the workers of the Phytopathology Department of the Plant Protection Institute.

Sincere thanks are also expressed to Doc. dr Anma Wilkojć and mg: Janina Schneider, both from the Department of Biology and Seeds Storage of the Plant Breeding and Acclimatization Institute, for their help with starting the storage experiments and for their actual contribution support during the proceedings of germination and storage of the seeds.

\section{REFERENCES}

Ames L. N., 1961, A monograph of the Chaetomiaceae. Budapest.

A rx J. A. von 1957, Revision der zu Gloesporium gestellten Pilze, Vehr. K. ned. Akad. Wet., Natuark. 51 (3): 1-153.

A rx J. A. von, 1974, The genera of fungi sporulating in pure culture, Bearn. Barnett H. L., 1960, Illustrated genera of Imperfect fungi, Minneapolis.

Barron G. L., 1972, The genera of hyphomycetes from soil, New York.

Benjamin C. R., 1955, Ascocarps of Aspergillus and Penicillium. Mycologia 47: 669-687.

Booth C., 1971, The genus Fusarium, C.M.I, Kew, Surrey.

B ooth C., 1975, The present status of Fusarium taxonomy. Ann, Rev. Phytopath. 13: 83-93.

Brown A, H, Smith G., 1957, The genus Paecilomyces Bainier and its perfect stage Byssochlamys Westling. Trans. Br. Mycol. Soc. 40: 17-89.

Brooks F. T., 1953, Plant disease, Cambridge-London.

Bruehl G. W., 1951, Rhizoctonia solani in relation to cereal crown and root rots. Phytopath. $41: 375-377$.

But le r S. J., J ones S. G,, 1955, Plant pathology, London.

Cassini R., 1970, Sur l'importance de la contamination des semences dans l'apparition et la maladie du pied des cereales due à Fusarium roseum (Link) Sn. et H. Ann. Acad, Sci. fenn., A 4, 168: 28-30. 
Chivers A. H., 1915, A monograph of the genera Chaetomium and Ascotricha. Mem. Torr. Bot. Club 14: 155-224.

( $:$ h r istensen C. M., Kaufmann H. H., 1965, Deterioration of stored grains by fungi. Ann, Rev. Phytopath. 3:69-84.

Christensen C. M., K a u f mann H. H., 1968, Grain storage, Minneapolis.

Colhoun .J, Park D., 1964, Fusarium diseases of cereals. I. Trans. Br. Mycol. Soc. 47: 559-572.

Colhoun J., Taylor G. S,, Tomlinson R., 1968, Fusarium diseases of cereals. II. Trans. Br. Mycol. Soc, 51: 397-404.

Cook R. J., 1968, Fusarium root and foot rot of cereals in the pacific Northwest. Phytopath. 58: 127-131.

Crosier W. F., Braverman S. W., 1963, Storage of fungi in seeds of small grains. Phytopath. 53: 348 .

Cauti E., Lemaire J. M., Ponchet J., Rapilly F., 1965, Exemples d'interactions fongiques au niveau de plantules de blé contaminées par l'Helminthosporium sativum. Ann. Epiph. 16: 37-44.

Dade H. A., 1949, Colour terminology in biology. Mycol, Pap. 6: 1-22.

Darpoux H., Ponchet J., 1957, Controle de l'état sanitaire et desinfections des semences. Proc. ISTA 22: 375-392.

Dommergues Y., Mangenot F,, 1970, Ecologie microbienne du sol, Paris.

Domsch K. H., Gams W., 1970, Pilze aus Agranboden. Stuttgart.

Dorenbosch M. M. J., 1970, Key to nine ubiquitous soil-borne Phoma-like fungi. Persoonia 6:1-14.

Dorenda M., 1974, Badania fitopatologicznego aspektu mikoflory ksztaltującej siç $W$ środowisku uprawnym pod wplywem zmianowania. Zesz. Probl. Post. Nauk Roln. 160: 113-150.

Dorywalski J., Wojciechowicz B., Bartz J., 1964, Metodyka oceny nasion. PWRiL, Warszawa.

Ellis J. J., Hesseltine C. W., 1965, The genus Absidia: Globosespored species. Mycol. 57: 222-235.

E 11 is M. B., 1971, Dematiaceous Hyphomycetes, C.M.I., Kew, Surrey.

Fields R. W., King T. H., 1962, Influence of storage fungi on the deterioration of stored pea seed. Phytopath, 52: 336-339.

Flamnigan B., 1970, Comparison of seed-borne mycofloras of barley, oats, and wheat. Trans. Br, Mycol. Soc, 55: 267-276.

Flannigan B., 1974, Distribution of seed-borne microorganisms in naked barley and wheat before harvest. Trans. Br. Mycol. Soc. 62: 51-58.

Flannigan B., 1978, Primary contamination of barley and wheat grain by storage fungi. Trans, Br. Mycol. Soc. 71: 37-42.

Gams W., 1971, Cephalosporium-artige Schimmelpilze (Hyphomycetes). Stuttgart.

Gil 1 m a n J. C., 1959, A manual of soil fungi, London.

Golubchuk M., Sorger-Domenigg H., Cuendet L. S., Christensen C. M., Geddes W. F., 1965, Grain storage studies, 19, Cereal Chem. 33: 45-52.

Hess W. M., Sassen M. M., Ramsen C. C., 1968, Surface characteristics of Penicillium conidia. Mycol. 60: 290-303.

Hess W. M., Stocks D. L., 1969, Surface characteristic of Aspergillus conidia. Mycol. 61: 560-571.

Hesseltine C. W., 1955, Genera of Mucorales with notes on their synonymy. Mycol. 47: $344-363$. 
Hesseltine C. W., Fennell D. I., 1955, The genus Circinella. Mycol. 47: 193-212.

Hewett P. D., 1967, A survey of seed-borne fungi of wheat. II. Trans. Br, Mycol, Soc. 50: 175-182.

Huguelet J. E., Kiesling R. L., 1973, Influence of inoculum composition on the black point disease of Durum Wheat, Phytopath, 63: 1220-1225.

Lityński M., Wiłkojé A., Schneider J., Koźmińska M., Urbaniak Z, 1960, Wytyczne do przechowywania nasion, Biul, IHAR 4(37): 3-29.

L i m o n a r d T., 1968, Ecological aspects of seed health testing. Inter. seed Test. Assoc., Wageningen.

Lopez L. C., Christensen C. M,, 1967, Effect of moisture content and temperature on invasion of stored corn by Aspergilius flavus. Phytopath., 57: $588-590$.

L utey R. W., Christensen C. M., 1963, Influence of moisture content, temperature, and lenght of storage upon survival of fungi in Barley Kemels. Phytopath., 53: 713-717.

Ea c i cowa B., 1963, Badania nad morfologią i biologią Fusarium poae (Pk) Wr. oraz patogenicznością tego gatunku względem siewek pszenicy. Ann, UMCS, C, 18 (17): 419-439.

E a ci cowa B., 1964a, Badania mikoflory materialu siewnego pszenicy uprawianej na obszarze woj. lubelskiego, uwzględniajace szczególnie grzyby patogeniczne. Ann. UMCS, E. 19(18): 381-406.

Eacicowa B., $1964 \mathrm{~b}$, Badania nad morfologią Helminthosporium triseptatum Dreschsl, oraz patogenicznością tego gatunku względem siewek pszenıcy. Ann. UMCS, C, 19, (18): 283-305.

Machacek J. E, Wa 11 ace H. B., 1952, Longevity of some common fungi in cereal seed. Canad. J. Bot. 30: 164-169.

Mala lasekera R. A. P., Tomlinson R., 1968, Fusarium diseases of cereals, 3. Trans, Br, Mycol, Suc, 51: 711-720.

Mal a lasekera R. A. P., Sanderson F. R., Cohoun. J., 1973, Fusarium diseases of cereals, 9, Trans. Br. Mycol. Soc. 60: 453-462.

Malone J. P., Muskett A. E., 1964, Secd-borne fungi. Proc, ISTA 2, 29: 179-384.

Mańka K,, 1953, Badania terenowe i laboratoryjne nad opicnką micdową Armillaria mellea (Vahl.) Oud., PWRiL, Warszawa.

M a ńk K., 1968, Some investigations on Fomes annosus Fr. carried out in Poland. Intern. Union of Foresty Res, Org. Sect. 24.

Mańka K., K ow a lski S., 1968, Wplyw zespolow grzybów glebowych z dwoch szkółek leśnych (susnowej i jesionowej) na rozwoj grzyba zgorzelowego Fusarium oxysporum Schlecht. Pozn. Tow, Przyj. Nauk, Wydz. Nauk Lesn. 25: 197-205.

Messiaen C. M., Lafon R., Molot P., 1959, Necroses de rancines, pourritures de tiges et verse parasitaire du mais. Ann. Epiph, 10: 441-474.

Miller J. J., 1946, Cultural and taxonomic studies on certain Fusteria. II, Canad. J. Res. 24: 213-223.

N a rkiew icz-J odk o M., 1978, Badania zdrowotnosici materialu siewnego przechowywanego w silosach bez dostępu powietrza. Zesz, Probl. Post. Nauk Roln, 202: 131-154.

Neergaard P., 1945, Danish species of Alternaria and Stemphylium, Copenhagen. 
Neerga ard P., 1977, Seed pathology. Copenhagen.

Nespiak A., 1963, Obserwacje nad występowaniem grzybów infekujących podstawę źdźbla zbóz na terenie Dolnego Sląska. Acta Agrobot. 14: 131-153.

Noble M., De Tempe J., Nee:gard P., 1958, An annotated list of seed-borne diseases. Proc. ISTA 24: 67-80.

Parmeter R., 1970, Rhizoctonia solani, Biology and Pathology. California.

Pokacka Z., Wojtaszek D., 1977, Z badan nad patogenicznością Rhizoctonia soluni Kühn na pszenicy i zycie. Materialy XVII Sesji Nauk. IOR, Poznan: 183-192.

R a i110 J, A, 1950, Griby roda Fusarium. Moskwa.

Raper K. B., Thom Ch., 1949, A manual of the Penicillia. Baltimore.

Raper K. B., 1957, Nomenclature in Aspergillus and Penicillium. Mycol. 49: 644-662.

Raper K. B., Fennel1 D. I., 1965, The genus Aspergillus. Baltimore.

Rifai M. A,, 1969, A revision of the genus Trichoderma. Mycol. Pap. 116: 1-56.

R y k a C., 1963, Disinfection of wheat seed singled out for laboratory investigations. R. A. M. $42: 674$.

Sauer D. B., Christensen C. M., 1966, Comparison of hard red spring and winter wheats in storage. Phytopath, 56: 619-623.

Simmons E. G., 1967, Typification of Alternaria, Stemphylium and Ulocladium. Mycol. 59: 67-92.

Sorger-Domenigg H, Cuendet L. S., Christensen C. M, Geddes W. F., 1955, Grain storage studies, XVII. Cereal Chem. 32: 270-285.

Truszkowska W., Schneider J., 1971, Ocena wartości siewnej i analiza mikologiczna owocków katranu abisyńskiego (Crambe abyssinica IJochst.) na tle doświadczen przechowalnianych. Zesz. Probl. Post. Nauk Roln. 113: 343-366.

Truszkowska W., Piekarska J,, Pietruszka B., 1971, Obserwacje wartości siewnej nusion niektórych odmian koniczyny czerwonej. Zesz. Probl. Post. Nauk Roln. 113: 329-341.

Truszkowska W., 1972, Badania zdrowotności i wartości siewnej przechowywanych nielupek slonecznika (Helianthus annuus L.). Biul. IHAR 1-2: 93-99.

Truszkowska W., Królowa D., Narkiewicz-Jodko M., 1972a, Badania zdrowotności i wartości materiału siewnego koniczyny krwistoczerwonej (Trifolium incarnatum I.) produkowanego $\mathrm{w}$ woj. opolskim. Biul. IHAR 1-2: 101-105.

Truszkowska W., Kocanda J., Maniecka J., Narkiewicz-Jodko M., 1972b, Grzyby zasiedlające nasiona esparcety i lubinu źółtego w warunkach doświadezen przechowalniczych. Biul, IHAR 1-2: 107-114.

Truszkowska W., Urban M., 1978, Badania zdrowotnośoi przechowywanych nasion maku oraz uzyskiwanych $\mathrm{z}$ nich wschodów. Zesz. Probl. Post. Nauk Roln, 202: 121-129.

Tuite J. F., Christensen C. M., 1957a, Grain storage studies, XxIII, Time of invasion of wheat seed by various species of Aspergillus responsible for deterioration of stored grain, and source of inoculum of these fungi. Phytopath. 47: $265-268$,

Tuite J. F., Christensen C. M., 1957b, Grain storage studies, XXIV, Phytopath: $47: 323-327$.

Tveit M., M oore M. B., 1954, Isolates of Chaetomium that protect oats from Helminthosporium victoriae. Phytopath., 44: 686-689. 
Warnock D. W., Preece I. F., 1971, Location and extent of fungal mycelium in grains of barley. Trans. Br. Mycol. Soc. 56: 267-273.

Whiteside W. C., 1961, Morphological studies in the Chaetomiaceae. Mycol. 53: $512-523$.

Wollenweber H., Reinking O. H., 1935, Die Fusarien, Berlin,

Z y cha H., Siejman $n$ R., Linneman n G., 1969, Mucorales. Hann, Münden.

\section{Grzyby występujące na materiale siewnym pszenicy jarej, ze szczególnym uwzględnieniem gatunków patogenicznych}

\section{Streszczenie}

Autor badał zbiorowiska grzybów związane z ziarnem pszenicy jarej w zależ" ności od warunków przechowywania ze szczególnym uwzględnieniem gatunków patogenicznych.

Ziarno pszenicy jarej odmiany 'Kolibri' o zawartości wilgoci $12 \%$ lub $15 \%$ bylo przechowywane $w$ temperaturze: zmiennej, $0^{\circ} \mathrm{C}$ lub $25-30^{\circ} \mathrm{C}$ przez 6,12 lub 18 mięsięcy. Przebadano zdolność kiełkowania ziarna wedlug ogólnie przyjętych zasad, Otrzymane wyniki wskazują, że żywotność ziarna zmniejszała się wraz $z$ czasem przechowywania, szezególnie w przypadkach, kiedy ziarno zawierało $15 \%$ wilgoci i bylo przechowywane w temperaturze zmiennej lub $25-30^{\circ} \mathrm{C}$. Analizy mikologiczne ziarna przeprowadzono metodą Ulsterską i zmodyfikowaną Ulsterskał. Ziarno bylo zasiedlone przez tzw. ,grzyby polowe”, wśród których najczęściej powtarzala się Alternaria alternata. Sklad gatunkowy grzybow zwiąanych z ziarnem przechowywanym był zróżnicowany i zależal raczej od warunków przechowywania niż od czasu przechowywania.

Sporadycznie wyosobniano $\mathrm{z}$ niedezynfekowanego świez.ego lub przechowywanego ziarna grzyby z rodzaju Fusarium (F. culmorum, F. poae, F. equiseti, F. semitectum, F. sporotrichioides).

Powiązania między grzybami wysteppującymi na ziarnie a zdrowotnościa wschodón badano na podstawie doświadczenia wazonowego. Wyniki tego doświadczenia wskazują na przenoszenie sị grzybów z ziarniaków na wschody oraz na duży m.in. wpływ mikoflory gleby na zdrowotność roślin; w warunkach ziemi nie sterylizowanej obserwowano wysoki procent wschodów i lepszy rozwój roślin. Rośliny wyrosłe w sterylizowanej ziemi częsiciej wykazywaly objawy zgorzeli podstawy źdźbla. Otrzymane wyniki dostarczają dowodu na zagrożenie pszenicy ze strony patogenicznych grzybów wystẹpujących na ziarnie. Mikologiczne analizy zoslin z objawami zgorzeli podstawy źdźbla pozwolily określić przyczyny choroby. $\mathrm{Z}$ organów chorych roślin wyosobniano glównie kilka gatunków z rodznju Fusarium: $F$. culmorum, $F$. equiseti, $F$. poae i $F$, semitectum. Pierwszy gatunek najczęściej byl przyczyną choroby zgorzeli podstawy źdżbła.

Wzajomne oddzialywanie pomiędzy grzybami z rodzaju Fusarium a innymj składnikami zbiorowisk wyosobnionych z ziarna lub chorych roślin przeanalizowano metodą szeregów biotycznych Manki (1968). Otrzymane wyniki wykazały, że grzyby z rodzaju Fusarium, patogeniczne dla pszenicy, przenoszące się $z$ materiałem siewnym nie znajdują antagonistów $w$ poznanych zbiorowiskach. Konsekwencją tego jest ciąglość choroby zgorzeli podstawy źdźbła. Z wyosobnionych z ziarna $i$ z chorych roślin grzybów z rodzaju Fusarium najbardziej wirulentnym okazal się gatunek Fusarium culmorum. 